\title{
Oorsigartikel - F. Gerrit Immink se prakties-teologiese studie van die geloofspraktyk: Liturgiese vernuwing in die Protestantse tradisie
}

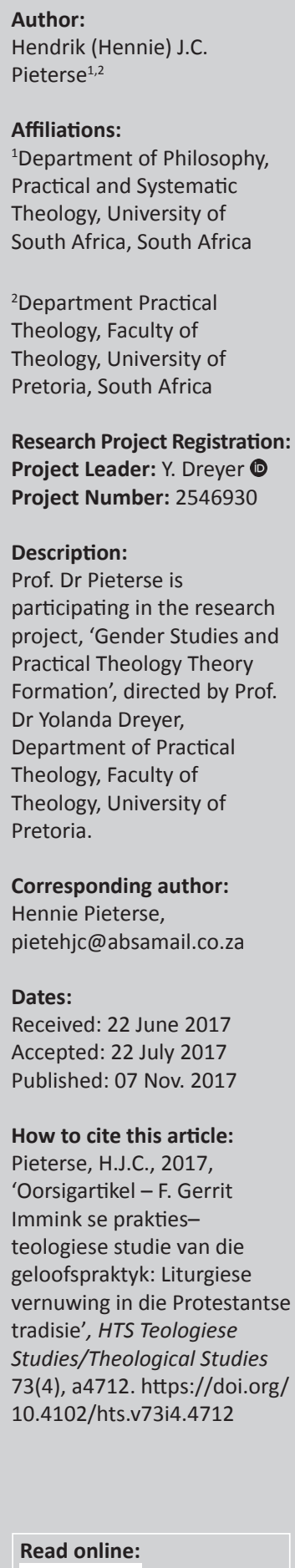

Corresponding author: Hennie Pieterse, pietehjc@absamail.co.za

Dates:

Received: 22 June 2017

Accepted: 22 July 2017

Published: 07 Nov. 2017

How to cite this article: Pieterse, H.J.C., 2017, 'Oorsigartikel - F. Gerrit Immink se praktiesteologiese studie van die geloofspraktyk: Liturgiese vernuwing in die Protestantse tradisie', HTS Teologiese Studies/Theological Studies 73(4), a4712. https://doi.org/ $10.4102 /$ hts.v73i4.4712

Read online:

\begin{abstract}
This contribution is a review article on the three most important books by F. Gerrit Immink in practical theology. His approach to this discipline is studying faith praxis of the Protestantse Kerk in Nederland (Protestant Church in the Netherlands) which is a church in the Reformed tradition. In his first book he explained his approach to practical theology in a discussion with the action theory and hermeneutical-communucative approaches. His choice for the study of faith praxis opens the way for a more theological approach to him in which communication between God and people is an important aspect. His second book forms the central part of this article. He uses the concept performance in the liturgy which is adopted from the theater world. In the performance by means of the execution of the liturgy by the congregation (preacher, organ, music, singing, praying) they all get involved in the message from the Bible of that Sunday, they are touched by it, it has an effect on them, and they get a new perspective on the problems of everyday life. This is possible through the work of the Holy Spirit. The epiclese prayers in the liturgy are prayers for the enlightening and work by the Spirit. He discusses singing, praying, preaching, baptism and Holy Communion in detail. The main idea is that the performance in the liturgy does something to you, it has an effect on you, something happens to you. To my mind there is no need to choose between the ritual approach and the approach he is putting on the table. The approaches can enrich each other.
\end{abstract}

\section{Inleiding}

Hierdie bydrae is 'n oorsigartikel oor die benadering tot en die hantering van die praktiese teologie deur F.G. Immink, tans emeritus professor van die Protestantse Theologische Universiteit, waar hy by die Universiteit van Groningen tot 2016 professor in homilitiek en liturgiek was. Die oorsigartikel dek sy drie belangrikste boeke in hierdie vak, naamlik Immink (2003), Immink (2011) en Immink (2016). Sy bydrae met die begrip performance wat in die boek oor die erediens uitgewerk word, plaas sy tweede boek (Immink 2011) dus in 'n belangrike posisie in hierdie oorsigartikel. Die bydrae van Gerrit Immink is myns insiens belangrik vir die Afrikaanssprekende kerke in die hervormde/gereformeerde geloofstradisie, omdat hy met grondige Reformatoriese teologie op so ' $n$ wyse werk dat dit in baie opsigte vir sommige mense in hierdie tradisie sin maak in die huidige samelewing in Nederland, maar ook in ons eie konteks in Suid-Afrika.

In die artikel sal ek eers Immink se benadering tot die vak beskryf in die lig van die verskillende wetenskaps-teoretiese benaderinge in die praktiese teologie sedert die sewentiger jare van die vorige eeu. Daarby kom ook sy teologiese posisionering binne die twee hoofstrominge in die protestantse teologie in Nederland. Daarna sal ek sy benadering tot die die erediens behandel, wat baie interessant is in die lig van die rituele benadering. Hy bied 'n ekstra perspektief daarby. Die artikel eindig met 'n konklusie.

\section{Benadering tot die praktiese teologie: 'n studie van die geloofspraktyk}

Die eerste boek (Immink 2003) is 'n sistematiese refleksie op die geloofspraxis. Daarin skenk hy aandag aan die eiesoortige karakter van die Christelike geloofslewe van mense en die opbou van

Copyright: @ 2017 . The Authors. Licensee: AOSIS. This work is licensed under the Creative Commons Attribution License.

Note: 'n Refleksie op Gerrit Immink se bydrae oor 'performance'. 'n Oorsigartikel van sy boeke In God geloven. Een praktisch-theologische reconstructie, Zoetermeer, Meinema, 2003; Het Heilige gebeurt. Praktijk, theologie en traditie van de protestantse kerkdienst, Zoetermeer, Boekencentrum, 2011; Bidden in het besef van Gods tegenwoordigheid, Zoetermeer, Boekencentrum, 2016. 
'n teoretiese kader waarin hy die geloofslewe kan analiseer (Immink 2003:9). In sy doktorale studie is hy geskool in teoretiese analise deur Prof. Vincent Brümmer (vgl. Brümmer 1975). Sy vermoë om begrippe (konsepte) in sy werk te analiseer asook sy kennis van die analitiese taalteorie, is opvallend. Maar sy blootstelling aan die empiriese metodes by NOSTER (Nederlandse Onderzoekschool voor Theologie en Religiewetenschap) het ' $n$ brug geskep om hom in die praktiese teologie te kan orienteer. Sy analitiese opleiding het hom in die praktiese teologie gehelp om die grondslae van die vak met teoretiese analises te analiseer. In sy werk hou hy die volgende sake byeen: teologiese inhoude, die alledaagse menslike lewe in die samelewing waarin die geloof beoefen word, en die kommunikasie met God en die tussenmenslike kommunikasie (Immink 2003:10). Om te glo is 'n sosiale en kommunikatiewe gebeure. Dit veronderstel die teenwoordigheid van andere, naamlik God en die medemense:

Het geloofsleven krijgt gestalte in intersubjektiewe betrekkingen ... Belangrike noties van het geloof zoals liefde, gerechtigheid en trouw komen tot uitdrukking in intersubjectieve betrekkingen. (Immink 2003:11)

In die laaste 30 jaar van die vorige eeu het daar nuwe benaderinge tot die praktiese teologie ontwikkel. In Nederland het J. Firet met die handelingsteorie in die vak begin werk in wat hy noem kommunikatiewe handelinge in diens van die evangelie met die belang van agogie (verandering) (Firet 1968, 1987). Gerben Heitink bou dit teoreties verder uit tot 'n prakties-teologiese handelingsteorie (Heitink 1993). Hy plaas die godsdienstige handelinge in 'n hermeneutiese, empiriese en strategiese perspektief (Immink 2003:34). Die Nederlandse praktiese teoloog J.A. van der Ven gebruik 'n empiriese benadering tot die vak en noem dit selfs empiriese teologie (Van der Ven 1990). Hy gebruik daarin 'n hermeneuties-kommunikatiewe aanpak, maar wat ook binne die handelingsteorie val (Immink 2003:34). G.D.J. Dingemans werk met ' $n$ hermeneutiese benadering geïnspireer deur Paul Ricoeur (Dingemans 1996).

In Immink se analise van die aard van die geloof sien hy die mens as 'n geestelike wese. Die idee van geleefde geloof (lived religion) wat in die laaste jare in ons na vore gekom het, het aangetoon dat die funksies van die gees van die mens 'n belangrike rol speel (Immink 2003:33). Hy is van mening dat daar in die handelingsteorie nie voldoende aandag bestee is aan hierdie feit nie. In plaas daarvan om hierdie grondbegrip van die mens as 'n geestelike wese te gebruik, word die mens in hierdie benadering te veel as handelende wese omskryf (Immink 2003:34). 'Geloven is niet alleen doen. Maar ook een geesteshouding' (Immink 2003:35).

Immink gee aandag aan die mens as 'n geestelike wese wat in staat is om met God te kommunikeer asook met medemense. Die mens het 'n houding, 'n geesteshouding (attitude), die mens kan ken, het 'n gevoel en 'n wil. 'Kennen, gevoelen en willen fungeren daarbij als een rubricerenvan de talloze functies die de menslijke geest verricht' (Immink 2003:31). Sodoende toon Immink dat hy selfs die insigte van die Sosiale Psigologie rakende die funksionering van gesindhede verreken. In sy boek beskou hy uitdrukkings soos die menslike gees, geestelike vermoëns, bewussyn en 'mentale leven' as sinonieme (Immink 2003:31). Die gelowige mens is vanweë sy/haar geestesvermoë in 'n eksistensiële betrokkenheid in die kommunikasie met God en medemense. By gelowige mense is daar ' $n$ verhouding met God en 'n kommunikasie met God soos dit in die gebed byvoorbeeld na vore kom. In hierdie God-en-mens verhouding ondervind die mens ook 'n werking van God in sy/haar lewe (Immink 2003:40-41).

Teenoor die handelingsteoretiese aanpak, stel G.D.J. Dingemans ' $n$ hermeneutiese benadering tot die praktiese teologie voor (Dingemans 1996). In die hermeneutiese rigting speel gesproke en geskrewe tekste ' $n$ belangrike rol. In so 'n ondersoek word gesoek na die betekenis en die interpretasie van tekste. Die handelinge van Christene in die praktyk is geïnspireer deur die evangelie van Jeus Christus. Tekste word herinterpreteer om sin te maak in die hede. Dingemans stel hom op teenoor die handelingsteoretiese aanpak en veral teenoor Van der Ven se empiriese teologie. Volgens Dingemans steun hierdie benaderinge (handelingsteoretiese aanpak) te veel op sosiaal-wetenskaplike insigte (Immink 2003:157). Immink stel vas dat volgens sy insig ons die geloofspraxis 'niet alleen maar kunnen benaderen vanuit een hermeneutische vraagstelling' (Immink 2003:191).

Immink werk met die vraag oor hoe God ter sprake kom. Hy aanvaar dat God 'n sprekende God is soos Hy homself geopenbaar het in die profetiese tradisie van die $\mathrm{Ou}$ Testament en in Jesus Christus soos ons dit in die Bybel vind. God is ook subjek en Hy praat en handel in die dialogiese verhouding van God en mens met mekaar (Immink 2003:165, 177). Die primaat van die Woord bring hy na vore in die gesprek van praktiese teoloë, waarin die gemeenskap tussen God en mens hoofsaaklik verstaan word as ' $n$ woordgemeenskap waarin God die inisiatief neem - dit is vir hom 'n sine qua non (Immink 2003:165-166). Die heil word bemiddel deur die lewende Woord in die Skrif deur die werk van die Heilige Gees wanneer hierdie Woord verkondig word. Die Woord word verstaan as belofte-God wat homself identifiseer as die God van Israel en die Vader van Jesus Christus is 'n betroubare spreker in die belofte in sy Woord (Immink 2003:233).Vir hom is 'n teologiese onderbou in die Praktiese Teologie uiters belangrik en dus dat die kommunikasie van die heil in Christus, soos ons teologie ons leer, in die geloofspraktyk 'n sleutelbegrip is (Immink 2003:121). Daarom spreek hy waardering uit vir die feit dat die handelingsteoretiese paradigma die aspek van kommunikasie in die geloofspraktyk so sterk na vore gebring het (Immink 2003:156). Maar hy het ook kritiek. Oor Dingemans se hermeneutiese benadering skryf hy soos volg:

In de analyse van de geloofspraxis schieten we echter tekort, wanneer we dat process van heilsbemiddeling enkel en alleen verklaren in termen van cultuurhistoriese overlevering (Immink 2003:191) ... Zowel in de empirische als in de hermeneutiesche praktische theologie is de tendens aanwezig om de werkelijkheid van God en de presentie van God in de geloofspraxis op een indirekte wijze te benaderen. Daardoor komt het theologische karakter van de praktische theologie minder uit de verfen wordt 
het onderscheidt met een menswetenschappelijke benadering van de godsdienstige praxis verdoezeld .... Die openbaring en dat heil zijn geen interpretaties van ons, maar woorden en dadenvan God. Daarmee komen we op een andere dimensie van de werklijkheid. De metafysische werkelijkheid van de gemeenschap tussen God en mens, waarin opgesloten ligt dat God zich sprekend en handelend tot de mens richt. De praktische theologie heeft zicht als theologische discipline met deze dimensie besig te houden. (Immink 2003:192)

Sy kritiek op die benaderinge wat hierbo bepreek is, is dat daar ' $n$ tendens is om die werklikheid van God en Sy teenwoordigheid op ' $n$ indirekte wyse in die geloofspraktyk te wil benader (Immink 2003). Ons kan nie die geloofspraktyk goed analiseer as ons God beperk:

... totvoorstellingen en opvattingen over God, of tot menslijke ervaringen van God, of tot 'God' als religieus symbool in een social-cultureel betekenissysteem. (p. 192)

Hy is van mening dat in die benaderinge wat hy bespreek het die teologiese gehalte nie goed genoeg vir 'n teologiese dissipline is nie. Agter die geloofspraktyk lê daar altyd 'n teologie. Daarom wy hy hoofstukke 4 en 5 aan 'n 'teologie van die praxis' (Immink 2003:79-118). Dit is 'n uiteensetting van die klassiek gereformeerde teologie aangaande die heil as gawe van God met 'n eksterne oorsprong, van God wat na die mense kom met die aanbod van die evangelie van Jesus Christus, wat in geloof ontvang word en in die alledaagse werklikheid uitgeleef word. Hy behandel die regverdigmaking (iustificatio) as die toerekening van God se kant af as eksterne geregtigheid wat aan die gelowige mens geskenk word. Die verwerkliking van die heil is die werk van die Heilige Gees in die lewe van die gelowige mens. Dit is 'n inwoning in die mens en ' $n$ aanraking in die innerlike van die mens, is sy geestesvermoë. Dit is 'n binding aan die openbaring van Christus. Om in God te glo is die aanvaarding van die lewe in die verwagting van die heil. Hoe word ons lewens vernuwe? Deur die gang van die gereformeerde siening van die ordo salutis. Dit is 'n lewe van stryd en aanvegting, maar met die onlosmaaklike binding aan die heil in Christus. Hierdie heil moet bemiddel word in die geloofspraktyk. Die ondersoek daarna (die heilsbemiddeling) is die taak van die praktiese teologie.

Hy kies dus as sy eie benadering tot die prakties-teologiese ondersoek die geloofspraktyk as navorsingsveld met 'n stewige hervormde/gereformeerde teologiese onderbou.

Immink beskou die intersubjektiewe verkeer tussen God en mens as die kern waarom dit in die geloofspraktyk gaan (Immink 2003:125; 2011:113). Dit geld die persoonlike geloofsverhouding maar ook die intermenslike verhoudinge, veral in die geloofsgemeenskap. In hierdie verhouding tussen God en mens/mense gaan dit om 'een persoonlijke ontmoeting, waarin we ons aangesproken weten door God' (Immink 2003:277). Die teenwoordigheid van God in die bewussyn van die gelowige mens is die werk van die Heilige Gees (Immink 2003:277). Om 'n goeie blik te kry op die teologiese insigte wat te make het met die verhouding tussen
God en mens en hoe God daarin ter sprake gebring word in die teologie, posisioneer hy hom tussen twee hoofstrome in die protestantse teologie in noordwes Europa (Nederland en Duitsland) met die oog daarop om van albei te leer oor die mens en oor God in hulle kommunikatiewe verhouding. Hy doen dit omdat hy oortuig is dat die verhouding tussen God en mens op verskillende maniere tot uitdrukking gebring word in die twee teologiese strominge. Hy ondersoek dus Karl Barth se openbaringsteologie in hierdie verband wat sterk klem op God lê, maar minder op die mens, en die antroposentriese teologie van die vrysinnige teologiese rigting wat klem lê op die mens se innerlike, maar minder op God.

Karl Barth (1964) skryf oor geloofskennis in die onderdeel van sy Godsleer. God praat in sy Woord oor die mens en Hy kom na die mens. Die spreke oor God vorm die uitgangspunt as ons oor die mens in hierdie verhouding wil dink (Immink 2003:209). In die verkondiging volgens Barth se teologie is dit 'n getuienis van die koms van God na die mens:

... terwijl de verlichting van en de verankering in de mens (de inwoning van de Geest) nauwelijks gethematiseerd worden ... De verankering van het geloof in het menselijk subject komt nauwelijks aan de orde ... Het tussenmenselijke discours wordt niet gethematiseert alseen zelfstandig onderzoeksobject van de praktische theologie. (p. 210)

In Immink se siening van die verhouding tussen God en mens word die menslike subjek ingeskakel in hierdie verhouding. Dit het nie voldoende ruimte in Barth se teologie nie, maar van God as ons teenóór (gegenständ) in die ongelyke verhouding waarin God eerste na ons toe kom, leer ons baie by Barth (Immink 2003:210):

God maakt zich bekend. Hij is de eerste in de ontmoeting en dat betekent ook dat Hij de gemeenschapt tot stand brengt. Er is sprake van een beweging van God naar de mens en alleen in die volgorde is er sprake van heil en leven. (p. 232)

In die antroposentriese perspektief gee Schleiermacher aan die menslike subjek 'n selfstandige plek, terwyl Barth die menslike subjek heeltemal in Christus plaas (Immink 2003:211). Volgens die antroposentriese teologie gaan dit in die geloofspraktyk oor die menslike subjektiwiteit wat sy oriëntasie punt in die omgewing van die sosiale werklikheid vind (Immink 2003:232). In die sosiale werklikheid ervaar die mens tekens van heil wat na God verwys. Oor God self kan 'n mens egter net tastend praat. Hy behoort tot ' $n$ onkenbare werklikheid en ons kan oor Hom slegs in ons verbeelding voorstellinge maak. Die invloed van die filosofie van die Verligting het 'n groot invloed op die antroposentriese model. Maar ons kan by hulle leer dat die mens in sy/haar subjektiwiteit en innerlike geestelike lewe ' $n$ plek het in die verhouding en kommunikasie tussen God en mens:

In deze studie heb ik geargumenteerd vanuit de these dat het in het geloofsleven gaat om een daadwerkelijke betrekking tussen God en mens ... Die betrekking kan alleen dan een levende gemeenschap zijn, wanneer God ook daadwerkelijk door de mens als subjek van spreken en handelen gekend word. (Immink 2003:232) 
Op grond van die analitiese taalfilosofie van Searle stel Immink dat die referensiële karakter van taal ons in staat stel om direk na God te verwys (Searle 1999:146-152):

Het onderscheid tussen een concept en de referent is van belang inde geloofsbetrekking tusen God en mens. Het biedt namelijk de mogelijkheid om op een evenwichtige manier om te gaan met het spanningsveld tussen de subject-- en objectzijde van de geloofsrelatie. We kunnen inderdaad spreken over ons begrip of concept van God. Ik spreekt liever niet over 'Godsbeelden', omdat daarmee te veel gesuggereerd wordt dat begrippen louter mentale voorstellingen zijn, terwijl een concept juist de verbinding met een externe werklijkheid legt. Het is een link. Als ik mij een begrip van iets vorm, dan begrijp ik iets. Als ikeen begrip van God heb, dan begrijp ik iets van God ... De begripsvorming veronderstelt dus de activiteit van het menselijk bewustzijn en is in die sin subjectief, dat het gekoppelt is aan de geestelijke activiteit van het menselijk subject ... Het bestaat juist in het kennen en begrijpen van een externe werkelijkheid. (Immink 2003:257)

\section{Die erediens en performance}

Immink is nie teen die rituele benadering tot die erediens nie. Sy uitgangspunt is die geloofspraktyk van die erediens. Die voorgangers (predikante, orreliste en andere) sowel as die gemeentelede is aktief betrokke in die uitvoeringspraktyk van die erediens. Daar word gebid en gesing in konkrete woorde. Die preek het 'n stilistiese en retoriese vorm en die kerkgangers word aangespreek en saamgeneem in die boodskap, of soms nie (Immink 2011:9). Die viering van die nagmaal en die bediening van die doop geskied in konkrete woorde en handelinge. In die nagmaal beoefen die gemeente die gemeenskap met Christus. Vir hierdie uitvoeringspraktyk is die kommunikatiewe en sosiale infrastruktuur uiters belangrik (Immink 2011:10). In die erediens speel die kunste, die musikaliteit, retorika en die rituele 'n rol. Hy verwys na Lukken in die verband (Lukken 1999). Die godsdienstige praktyk van die erediens het ook 'n teologiese onderbou waarin die geloof van die gemeente uitgedruk word. Maar met die teologiese oorweginge is daar ook godsdienswetenskaplike insigte wat ' $n$ rol in die erediens speel (Immink 2003:10). Die rituele is dus deel van die verskillende sake wat die erediens 'n erediens maak. As hy oor die preek skryf as deel van die liturgie sê hy doodgewoon: 'Rituele of sacramentele handelinge zijn niet 'zwaarder' performatief geladen dan de preek' (Immink 2011:43). Rituele speel duidelik 'n rol. As hy die Reformatoriese en die Rooms-Katolieke erediens-gebruike bepreek oor die aktualisering van die teenwoordigheid van Christus in die liturgie waarin die rituele 'n rol speel, stel hy dat albei kerkgenootskappe met dieselfde saak besig is. 'Hoewel er verschillen zijn, gaat het hier in de kern wel om dezelfde thematiek: de actuele gemeenschap met Christus' (Immink 2011:12). In die hervormde/gereformeerde erediens is die bede om die Heilige Gees (epiclese) die punt waar daar vertrou word dat God deur sy Gees werksaam sal wees in die gebeure van die erediens (Immink 2011:77-82):

In de protestantse traditie wordt die werkzaamheid niet primair gelokaliseerd in het kerkelijk ritueel, maar leeft de gedachte dat God bezig zal zijn met de samengekomen gemeente, met de kerkgangers. (Immink 2003:82-83)
Hy praat dus van 'nie primêr nie' - dus speel die rituele in die liturgie by hom 'n rol. Maar hy wil iets meer sê oor die optrede in die erediens, die gebeure wat deur die werk van die Heilige Gees tot 'n godsdienstige belewenis kan word. Daarvoor gebruik hy die performance idee. Dit korreleer met die idee van teonome resiprositeit, naamlik dat die dieper betekenis van die erediens ook menslike deelname verreken.

Immink gebruik die begrip performance as 'n sleutel begrip in sy behandeling van die gebeure in die erediens. Om die moontlike vreemdheid van hierdie begrip nader te bring aan wat aan ons bekend is, verduidelik hy dit soos volg:

Wat is de performatiewe karakter van de kerkdienst? Het antwoord op deze vraag wordt vaak verpakt in theologische taal. Bijvoorbeeld in uitdrukkingen zoals 'de liturgische werking van de kerkdienst', of 'het sacramentele karakter van het avondmaal', of 'de prediking is bediening van het Woord van God'. (Immink 2011:12)

Die haas onvertaalbare begrip performance het te doen met 'n taalhandeling. Taalhandelinge het ' $n$ aktualiserende werking. 'In de performance gebeurt iets. Met de term performance word het beeld van het theater opgeroepen' (Immink 2003:29). Die uitvoeringspraktyk wat in die erediens verrig word, is 'n performance. Hy verwys na David Plüss (2007) en Jana Childers (1999) wat met dieselfde benadering werk. Die akteurs voer 'n toneelstuk op (perform) met 'n spesifieke verhaal. Die teatergangers raak betrokke by die verhaal wat opgevoer word. Daar gaan 'n wedersydse energie uit. Die teatergangers identifiseer met karakters en insigte en word geraak daardeur. Dit verander hul insig en perspektief op die stuk werklikheid van die lewe wat daar in die performance ten tonele gestel is. Tekste uit die Skrif het ook 'n soortgelyke werking waardeur mense geraak word en selfs tot verandering kom in die erediens (Immink 2003:30; Plüss 2007:227). Die verhaal van Jesus Christus, of die spesifieke gedeelte uit die Skrif en bypassende liedere en gebede wat op die aktualiteit van die dag gerig is die spesifieke Sondag, word deur die voorgangers uitgevoer, performed, ten tonele gebring, in die erediens. Daar gaan 'n wedersydse energie uit. Die gemeentelede raak betrokke by die prediking en die viering van die sakramente, die gebede en die liedere. Hulle word geraak daardeur. 'Tijdens de kerkdienst wordt het menslijke zelf- het geheel van gedachten, overleggingen, neigingen, strevingen, verlangens en gevoelens - actief werkzaam' (Immink 2011:41). Deur die werk van die Gees word hulle 'n nuwe perspektief gegee op die aktualiteit van die dag en tyd. So gebeur dit in die erediens waar die geloof geaktiveer word, maar ook in die persoonlike gebed is die biddende mens in gesprek met die lewende God in 'n gebeure waarby God en mens albei betrokke is (Immink 2016:140). Daar gebeur iets in die erediens deur die performance van voorgangers en kerkgangers tesame.

In ons tyd word baie aandag gegee aan die performatiewe werking van die gesproke woord. Dat 'n mens iets doen met gesproke taal in die tussenmenslike kommunikasie is vandag in die taalfilosofie algemene kennis (Immink 2011:44; vgl. Brümmer 1975). So is die preek 'n taalhandeling. Die 
belangstelling in die werking van taal in die eietydse homiletiek is ook versterk deur die invloed van die performance studies (Immink 2011):

Performance language is een term die voorkomt uit een theorie over de werking van taal in tussenmenselijke communicatie ... Door gebruik te maken van de taaldadentheorie en de performancestudies beschikken we nu over een theoretisch kader waardoor we meer inzicht krijgen in de kracht van het gesproken word. (p. 44)

Die taalgebruik van die prediker en liturg het 'n werking en 'n invloed in die kommunikasie tussen spreker en hoorder. Hierdie gebeure neem die Heilige Gees in diens in die erediens (Immink 2011:57-59). 'De begrippen performance en performativiteit helpen ons om beter zicht te krijgen op de communicatie in de kerkdienst' (Immink 2011:45). Volgens Immink is dit ' $n$ aspek wat nie baie aandag in die verlede ten opsigte van die erediens gekry het nie (Immink 2011:45).

Die erediens is ' $n$ godsdienstige praxis. Alle mense wat die erediens meemaak, is besig met die performance. Kerkgangers verrig verskillende verbale en nie-verbale handelinge in die erediens. Daar is momente waar hulle self die woord neem, soos byvoorbeeld in die gemeentesang. Protestantse gemeentes is singende gemeentes (Immink 2011:16-17). Deur hul betrokkenheid aan die hele gebeure is hulle deel van die performance wat bedoel is om 'n nuwe perspektief op die aktualiteit of probleem van die dag te bewerk wanneer die Skrif se lig daarop val. 'Lofsprijzing en aanbidding hebben een zelfstandige plaats in de protestantse kerkdienst gekregen' (Immnk 2011:18). Die Heer spreek ons aan deur sy Woord en dat '... wij op onze beurt met hem spreken door gebed en lofgezang' (Immink 2011:18). Die erediens bied ruimte waarin gelowiges uiting kan gee aan vreugde, dankbaarheid, verdriet en hul nood. Die gemeentesang bied ruimte vir al hierdie emosies, behoeftes en gebede. In die kerklike liedboeke van die Reformatoriese kerke word haas alle aspekte van die menslike lewe gedek en kan die sang aktueel aangewend word om uitdrukking te gee aan die gemeente se gevoelens by die aktuele sake wat die spesifieke dag ter sprake is (Immink 2011:22):

\footnotetext{
In de gebeden en in de liederen worden teksten op een bijzonder effectieve wijze in scène gezet. De bidder en de zanger worden door de performance van het gebed, c.q. het gezang, in een bepaalde scène verplaats, waar ze zicht slechts met moeite aan kunnen ontrekken. $\mathrm{Zij}$ raken helemaal in de scène thuis en bidden --zonder noemenswaardige geestelijke inspanning, als het ware prereflexief - het ' $\mathrm{ik}$ ' en het 'wij' van het gebed mee. Ze zingen zo, alsof ze het lied voor eerst en spontaan zingen, en treden op die manier in een scenisch contact met God. Zingend en biddend laten ze zich door God aanspreken en geven ze antwoord. (Immink 2011:30; vgl. ook Plüss 2007:227)
}

In die gebed van die gelowige mens in die persoonlike lewe en die gebede in die erediens verwag hy/sy, in die besef van God se teenwoordigheid, 'n lewende, eksistensiële ontmoeting met God ook op grond van die verbondsverhouding met Hom (Immink 2016:96-97, 202). Geloof in die kruis en opstanding van Jesus Christus is essensieël en die werking van die heil in ons lewens is deur die Drie-enige God: Vader, Seun en Heilige Gees.

Om te bid is om in gesprek met God te tree. Op grond van 'n deeglike eksegese oor gebed in die $\mathrm{Ou}$ en Nuwe Testament stel Immink dat ons in gebed oor ons nood kan vra, ook danksegging en lof hoort daarby en voorbidding vir die gang van die evangelie en vir alle mense. Die aard van God se teenwoordigheid het 'n meervoudige gestalte in die gebed. As Skepper onderhou en versorg hy ons lewe - dit bied vertroue en gee 'n anker; as ons in die naam van Jesus Christus bid, glo ons dat hy ons sonde versoen het, die lyding van die wêreld dra, die dood oorwin het en ons red van ondergang; die Heilige Gees werk in ons lewe en tydens ons gebed - hy gee ons insig in die waarheid van God, maak ons deel van die verlossing in Christus en inspireer ons tot ' $n$ nuwe lewe (Immink 2016:2016). So vertrou die bidder op God in 'n lewende, eksistensiële kontak met Hom.

By die doop moet ons, volgens Immink, die Christus geheim bedink van die opstanding na die kruisiging. In die geloofspraktyk van die erediens is die belydenis van die opgestane Heer fundamenteel. 'Hij is namelijk de presente Christus van het geloof' (Immink 2011:119). Hy sluit aan by Paulus en Bultmann in 'n diepgaande diskussie oor die opstandingsgeloof van die dissipels en die eerste gemeente, met 'n bespreking oor die eskatologiese dimensie van die opstanding. Kruis en opstanding behoort nie losgekoppel te word nie:

In de theologie en antropologie van Paulus komt duidelik naar voren dat het kruis en opstanding van Christus hun beslag leggen op het leven van mensen ... Kruis en opstanding vormen het hart van de kerkdienst en van het kerkelijk jaar. Het blijft echter een geheimenis. (Immink 2011:116)

Die doophandeling is 'n eenvoudige handeling met water en die woorde: Ek doop jou in die naam van die Vader en die Seun en die Heilige Gees. Dit kom reeds van die begin af en word in die Didachè beskryf soos ons dit vandag nog doen in die kerke (Immink 2011:162). Hy hou van die bewoording van die formuliere soos dit deur die kerk opgestel is waarin die belangrikste inhoud by die doop en die nagmaal woordeliks oorgedra kan word (Immink 2011:296-306). Hy beveel ook aan dat die liturgiese gebede soos aanvangsgebede by die begin van die diens, by die verootmoediging en skuldbelydenis gebruik moet word soos die kerk dit in die diensboek opgestel het (Immink 2011:197-202):

Het liturische gebed is vanwege zijn publieke karakter onderscheiden van het persoonlijke gebed en het pastorale gebed in een gespreksituatie. (p. 206)

Die preek is deel van die performance in die liturgie. Die preek kan bydra tot iets wat gebeur in die erediens sodat die gemeentelede 'n nuwe kyk, 'n nuwe perspektief op sake kan kry in die lig van God se siening daarvan. Die preek as performance is meer as net 'n retoriese en taalhandeling - die lewe en die geloof van die erediensgangers kom ter sprake. Die lewens van die gelowiges in die kerk word aangeraak in die verbinding met die Bybelse boodskap deur die werk van 
die Gees. In die liturgie is immers voor die preek in die epiklese gebid om die verligting van die Heilige Gees terwyl die Woord geskied in die Skriflesing en preek. Dit beteken dat die Skrif nie dooie letters op papier is nie, maar die lewende Woord van God: '... een woord die heil brengt. De preek als performance heeft een heiligende werking' (Immink 2011:219).

In sy beskrywing van hoe die preek tuis kom by die hoorders van die preek maak Immink gebruik van die bevindinge van Theo Pleizier se proefskrif, 'n doktorale student van hom en ook sy opvolger as professor (Pleizier 2010). Die hoorders raak intensiewer en meeer bewustelik betrokke by die preek as hulle 'n verband kan sien tussen die preek en hulle eie lewe (Immink 2011:231). Hierdie insig het Immink ook begin volg in sy hoofstuk in die boek van Van der Meulen, naamlik dat die preekproses begin by 'n besinning op die leefwêreld van kerkgangers en die sosiaal-maatskaplike konteks (Van der Meulen 2008:14). Dit is ' $n$ benadering tot die begin-proses in preekvoorbereiding voordat die eksegese van die Bybelse teks met die oog op die preek aangepak word, wat Pieterse voorheen al gestel het op grond van eie empiriese ondersoeke (Pieterse 2001:86-88; vgl. Pieterse 1995; 2001).

Die godsdienstige lewe van die predikant speel ook 'n rol in die ontvangs van die boodskap van die preek. Dit is nie net ' $n$ goeie retoriese en kommunikatiewe vaardigheid van die prediker wat belangrik is nie, maar ook sy eie geloof. 'De predikant word gezien als een medegelovige' (Immink 2011:231). Hoe meer betrokke die kerkgangers is by die eerste deel van die liturgie voor die preek, hoe meer eksistensiëel en geloofsmatig is hulle betrokke in die preek (Immink 2011:232). Die performance van die liturgie van die begin van die diens af is dus uiters belangrik. Die preek is ook baie belangrik vir die geloof van die lidmate. Gereelde kerkgangers se geloof word ook deur die preek versterk. 'De preek houdt de gedachtenis van Christus levend' (Immink 2011:233). By die preekvoorbereiding is die histories-literêre eksegese belangrik, maar daarna ook die homileties-teologiese konstruksie van die boodskap (Immink 2011:244). Daarin speel die vasstel van die fokus van die teks wat die fokus van die preek behoort te word, 'n belangrike rol (Immink 2011:258). 'De preek als performance heeft een actualiserende werking' (Immink 2011:290). Dit open nuwe perspektiewe en bou hoop en geloof in die moeilikste omstandighede.

Die nagmaal word gewoonlik na die preek gebruik. Immink wy 'n hele aantal bladsye aan die historiese ontwikkeling van die nagmaal na die Hervorming in die sestiende eeu onder die tema 'De wording van de gereformeerde avondmaalsliturgie' (Immink 2011:296). Hy dek die ontwikkeling van Straatsburg en Genève, die Paltz en die ontwikkelinge in Nederland (Immink 2011:296-305). Ons huidige nagmaalsbeskouing en gebruik stam op die Nederlandse variant in die ontwikkeling van die nagmaalsbeskouinge van die hervormde/ gereformeerde kerke:

De liturgische performance, de distributie van brood en wijn én het eten en drinken worden direct verbonden met de werking van de Heilige Geest. Hier realiseert zich de gemeenschap met Christus. (Immink 2011:306-307)
Daarom is die epiklese gebed aan die begin van die nagmaalsliturgie by die tafel so belangrik waar gebid word om die werking van die Gees by die viering van hierdie sakrament. By die vraag oor die teenwoordigheid van Christus in die erediens bespreek hy deurgaans die Rooms-Katolieke verstaan van die misoffer en ons verstaan van die teenwoordigheid van Christus deur die werking van sy Gees vanweë die epiklese gebede voor die doop, die preek en die nagmaal waarin gebid word om die verligting en teenwoordigheid van die Gees in al ons handelinge as performance.

Met die verskyning van die Dienstboek oor die liturgiese vormgewing van die nagmaalsvieringe as voorloper vir die Protestantse Kerk in Nederland is volgens Immink 'n nuwe mylpaal bereik. Dit bevat twee uitgewerkte liturgieë: in die eerste word die protestants-ekumeniese viering in die vorm van 'n tafelgebed aangebied en die tweede in onderwysende vorm in die gees van die gereformeerde tradisie. Sowel die klassiek gereformeerde as die protestantsekumeniese nagmaalsvieringe vertoon ' $n$ vaste patroon (Immink 2011:321, 323). In die eerste is daar 'n lopende kommunie en in die tweede 'n sittende kommunie rondom die tafel. In beide word die geheim van Christus bewaar:

De avondmaalsliturgie - hetzij in de vorm van een onderwijzende lofprijzing, hetzij in de vorm van een tafelgebed - heeft tot taak de avondmaalsvierdende gemeente bij het geheim van Christuste bewaren. Dat is een kerkelijke verantwoordelijkheid die ook tot uitdrukking komt in de liturgische vormgeving van de avondmaalsviering. Wanneer dat bezef aanwezig is, worden vorm en vrijheid,script en Geest niet langer tegen elkaar uitgespeeld, maar verrijken ze elkaaar. (Immink 2011:326-327)

\section{Konklusie}

Die laaste sin in die aanhaling uit Immink (2011:327) se boek hierbo ten opsigte van die verskillende wyses van nagmaal vier, is ook my oorweging by die beoordeling van sy bydrae tot die liturgie in die lig van die rituele benadering met die baanbrekende boek van Barnard, Cilliers en Wepener (2014). Uit sy boek blyk dat Immink nie teen die rituele benadering is nie en skryf byvoorbeeld op sommige plekke van die ritueel van die doop en die nagmaal. Immink skryf vir 'n leserspubliek in die hervormde/gereformeerde tradisie in Nederland. Dit is sy reikwydte. Hy het volgens my egter nog 'n aspek op die tafel gesit, wat in die lig van sy teologiese uiteensetting en die werk van die Heilige Gees (epiklese in die liturgie), die moontlikheid open dat die erediensgangers van die hervormde/gereformeerde kerke ' $n$ belewenis kan hê van 'n veranderde kyk en verstaan van die saak uit die Skrif - anders as die gangbare manier van kyk na probleme. Ek dink nie dit is nodig om die twee benaderinge teen mekaar uit te speel nie, hulle verryk mekaar.

\section{Erkenning Mededingende belange}

Die outeur verklaar dat hy geen finansiële of persoonlike verbintenis het met enige party wat hom nadelig kon beïnvloed het in die skryf van hierdie artikel nie. 


\section{Literatuurverwysings}

Barnard, M., Cilliers, J.\& Wepener, C., 2014, Worship in the network culture. Liturgical ritual studies. Fields and methods, concepts and metaphors, Uitgeverij Peeters, Leuven.

Brümmer, V., 1975, Wijsgerige begripsanalyse. Een inleiding voor theologen en ander belangstellenden, Kok, Kampen.

Childers, J., 1999, Performing the word. Preaching as theater, Abingdon Press, Nashville.

Dingemans, G.D.J., 1996, Manieren van doen. Inleiding tot de studie van de praktische theologie, Kok, Kampen.

Firet, J., 1968, Het agogisch moment in het pastoral optreden,Kok, Kampen.

Firet, J., 1987, Spreken alseen leerling. Praktisch-theologische opstellen,Kok, Kampen. Heitink, G, 1993, Praktische Theologie. Geschiedenis, theorie, handelingsvelden,Kok, Kampen.

Immink, F.G., 2003, In God geloven. Een praktisch-theologische reconstructie, Meinema, Zoetermeer.

Immink, F.G., 2011, Het Heilige gebeurt. Praktijk, theologie en traditie van de protestantse kerkdienst, Boekencentrum, Zoetermeer.
Immink, G., 2016, Bidden in het besef van Gods tegenwoordigheid, Boekencentrum, Zoetermeer.

Lukken, G., 1999, Rituelen in overvloed: Een kritische bezinning op de plaats en de gestalte van het chritelijke ritueel in onze cultuur, Gooi \& Sticht, Baarn.

Pieterse, H.J.C. (ed.), 1995, Desmond Tutu's message. A qualitative analysis, Kok Pharos/Weinheim, Deutscher Studien Verlag, Kampen.

Pieterse, H.J.C., (ed.), 2001, Desmond Tutu's message. A qualitative analysis, 2nd edn., Brill, Leiden.

Pieterse, H.J.C., 2001, Prediking in 'n konteks van armoede, Unisa Uitgewers, Pretoria.

Pleizier, T., 2010, Religious involvement in hearing sermons. A grounded theory study in empirical theology and homiletics, Eburon Academic Publishers, Delft.

Plüss, D., 2007, Gottesdienst als Textinszenierung. Perspektiven einer performativen Ästhetik des Gottesdienst, Tvz-Theologischer Verlag, Zürich.

Searle, J.R., 1999, Mind, languge and society. Philosophy in the real world, Basic Books, New York.

Van der Meulen, H., (red.), 2008, Als een leerling leren preken. Preekvoorbereiding stapsgewijs, Boekencentrum, Zoetermeer, pp. 9-20.

Van der Ven, J.A., 1990, Entwurf einer empirischen Theologie, Kok/Weinbach, Deutsche Studien Verlag, Kampen. 